\title{
Sonic hedgehog promotes somitic chondrogenesis by altering the cellular response to $\mathrm{BMP}$ signaling
}

\author{
L. Charles Murtaugh, Jay H. Chyung, and Andrew B. Lassar ${ }^{1}$ \\ Department of Biological Chemistry and Molecular Pharmacology, Harvard Medical School, Boston, \\ Massachusetts 02159 USA
}

Previous work has indicated that signals from the floor plate and notochord promote chondrogenesis of the somitic mesoderm. These tissues, acting through the secreted signaling molecule Sonic hedgehog (Shh), appear to be critical for the formation of the sclerotome. Later steps in the differentiation of sclerotome into cartilage may be independent of the influence of these axial tissues. Although the signals involved in these later steps have not yet been pinpointed, there is substantial evidence that the analogous stages of limb bud chondrogenesis require bone morphogenetic protein (BMP) signaling. We show here that presomitic mesoderm (psm) cultured in the presence of Shh will differentiate into cartilage, and that the later stages of this differentiation process specifically depend on BMP signaling. We find that Shh not only acts in collaboration with BMPs to induce cartilage, but that it changes the competence of target cells to respond to BMPs. In the absence of Shh, BMP administration induces lateral plate gene expression in cultured psm. After exposure to Shh, BMP signaling no longer induces expression of lateral plate markers but now induces robust chondrogenesis in cultured psm. Shh signals are required only transiently for somitic chondrogenesis in vitro, and act to provide a window of competence during which time BMP signals can induce chondrogenic differentiation. Our findings suggest that chondrogenesis of somitic tissues can be divided into two separate phases: Shh-mediated generation of precursor cells, which are competent to initiate chondrogenesis in response to $\mathrm{BMP}$ signaling, and later exposure to $\mathrm{BMPs}$, which act to trigger chondrogenic differentiation.

[Key Words: Somites; chondrogenesis; sonic hedgehog; BMPs]

Received August 6, 1998; revised version accepted November 23, 1998.

After amniote gastrulation, the paraxial mesoderm lying adjacent to the neural tube and notochord undergoes segmentation into metameric blocks of tissue, the somites. Initially epithelial, each somite differentiates according to a stereotypical program: the ventral region becomes mesenchymal and forms the sclerotome, precursor to the vertebrae and the medial part of the ribs; the dorsal region, termed the dermomyotome, remains epithelial and contains precursor cells for skeletal muscle, dermis, and the lateral part of the ribs (see Kato and Aoyama 1998 and references therein). The various cell fates within the somite are plastic and appear to depend on signals from surrounding tissues. In particular, dorsally generated derivatives such as muscle require signals from either the dorsal neural tube or surface ectoderm (Avery et al. 1956; Vivarelli and Cossu 1986; Kenny-Mobbs and Thorogood 1987; Christ et al. 1992; Rong et al. 1992; Buffinger and Stockdale 1994; Fan and Tessier-Lavigne 1994; Buffinger and Stockdale 1995; Cossu et al. 1995; Gamel et al. 1995; Münsterberg et al. 1995; Stern et al. 1995; Stern and

${ }^{1}$ Corresponding author.

E-MAIL lassarab@warren.med.harvard.edu; FAX (617) 738-0516.
Hauschka 1995; Spence et al. 1996; Dietrich et al. 1997), whereas the ventrally situated sclerotome is generated in response to a common signal from the floor plate and notochord (Holtzer and Detwiler 1953; Watterson et al. 1954; Grobstein and Holtzer 1955; Hall 1977; Brand-Saberi et al. 1993; Dietrich et al. 1993, 1997; Goulding et al. 1993; Koseki et al. 1993; Pourquié et al. 1993; Ebensperger et al. 1995). The dorsal and ventral signals appear to be antagonistic: embryos genetically or surgically manipulated to lack both floor plate and notochord show a ventral expansion of the domain of dermomyotomal gene expression and a subsequent absence of sclerotome and vertebrae (Watterson et al. 1954; Dietrich et al. 1993, 1997; Goulding et al. 1993; Monsoro-Burq et al. 1994; Ebensperger et al. 1995). Conversely, grafting an ectopic notochord or floor plate adjacent to the dorsomedial somite produces ectopic sclerotome at the expense of dermomyotome (Brand-Saberi et al. 1993; Goulding et al. 1993; Pourquié et al. 1993; Ebensperger et al. 1995; Dietrich et al. 1997). The signaling properties of the ventral midline tissues can be mimicked in vivo and in vitro by the secreted signaling molecule Sonic hedgehog (Shh), which also promotes the growth and survival of somitic 
cells (Fan and Tessier-Lavigne 1994; Johnson et al. 1994; Fan et al. 1995; Münsterberg et al. 1995; Borycki et al. 1998; Teillet et al. 1998).

Once formed, the sclerotome migrates medially to surround the neural tube and notochord and laterally to give rise to the ribs, before differentiation into cartilage-producing chondrocytes (Christ and Wilting 1992). Mice engineered to lack Shh fail to form vertebrae (Chiang et al. 1996), indicating that Shh is absolutely required for the formation of vertebrae in vivo. A number of observations suggest that although Shh is required for induction of sclerotome, the subsequent differentiation of sclerotome into cartilage may not depend on maintained Shh signaling. During the course of vertebral development, expression of the early sclerotome marker and Shh target gene Pax-1 is lost in sclerotomal cells that move dorsally to give rise to the neural arches and is eventually shut off in all differentiating chondrocytes (Deutsch et al. 1988; Ebensperger et al. 1995; Peters et al. 1995), suggesting that Shh signals may be received only transiently by these cells. Furthermore, whereas psm and somites isolated from young chick embryos will not differentiate into chondrocytes in the absence of cocultured ventral midline tissues, these paraxial mesodermal tissues isolated from progressively older chick embryos display an increasing capacity to form cartilage when cultured in the absence of notochord and floor plate (Watterson et al. 1954; Avery et al. 1956; Ellison et al. 1969). Taken together, these studies suggest that there are at least two distinct phases in the formation of vertebral cartilage: Shh-dependent formation of sclerotome, and the subsequent differentiation of this tissue into chondrocytes, which can occur in the absence of maintained Shh signals.

Cartilage differentiation has been studied intensively in the context of limb development. This work has led to an appreciation of the critical role played by the bone morphogenetic proteins (BMPs) in the formation and differentiation of cartilage. Misexpression of BMPs or of activated BMP receptors in the limb bud results in ectopic chondrogenesis, and in extreme cases converts virtually the entire limb mesenchyme into cartilage (Duprez et al. 1996; Zou et al. 1997). Conversely, inhibiting BMP signaling with dominant-negative receptors or with the soluble BMP antagonist Noggin inhibits the formation of cartilage in vivo and in vitro (Kawakami et al. 1996; Zou et al. 1997; Capdevila and Johnson 1998). Thus, BMPs play a crucial role in cartilage formation in the limb; however, it remains unclear whether BMPs act to specify cartilage precursor cells in the limb bud or act to facilitate their differentiation. In micromass cultures, BMPs appear to act only after the formation of visible mesenchymal condensations (Roark and Greer 1994), suggesting that their role is relatively late. In addition, competence to respond to BMPs changes during the course of limb bud outgrowth, such that ectopic BMP signaling leads to apoptosis during early limb bud stages and promotes chondrogenesis at later times (Macias et al. 1997; Zou et al. 1997; Buckland et al. 1998).

Previous studies suggests that BMP signals may simi- larly affect somitic chondrogenesis (Monsoro-Burq et al. 1996; Brunet et al. 1998). However, the response of sclerotomal cells to BMP signaling seems to vary in different regions of the somite. Whereas implantation of BMP-producing cells in the region of the prospective dorsal vertebra induces enlargement of the spinous process, implantation of these cells directly adjacent to the somite entirely blocks vertebral formation (Monsoro-Burq et al. 1996). As well as modulating somitic chondrogenesis, BMP signaling is also known to affect other aspects of somite patterning. BMP signals negatively regulate the spatial and temporal activation of somitic myogenesis (Reshef et al. 1998) and positively regulate lateral somitic cell fates (Pourquié et al. 1996; Tonegawa et al. 1997). In addition, BMP signaling acts to subdivide the mesoderm into paraxial and lateral domains, such that increasing exposure to BMP signals specifies progressively more lateral cell fates (Harland 1994; Re'emKalma et al. 1995; Schmidt et al. 1995; Dosch et al. 1997; Tonegawa et al. 1997). In vitro, somites treated with high levels of BMP2, BMP4, or BMP7 are inhibited from expressing either myotomal or sclerotomal markers in response to signals from the axial structures, and instead activate lateral plate markers (McMahon et al. 1998; Reshef et al. 1998). Treating somites in vivo with low doses of BMP2 or BMP4 leads to an expansion of lateral cell fates within the somites and, at higher doses, to an extinction of all somitic cell fates and ectopic expression of lateral plate mesoderm markers (Pourquié et al. 1996; Tonegawa et al. 1997).

In this work, we take advantage of an in vitro culture system to examine the particular roles of Shh and BMP signaling in promoting chondrogenesis of isolated presomitic mesoderm (psm). We find that Shh induces not only early sclerotomal markers, as shown previously (Fan and Tessier-Lavigne 1994; Münsterberg et al. 1995), but also suffices to elicit chondrogenesis in cultured psm. Shh-induced somitic chondrogenesis requires active BMP signaling, as seen previously in limb mesoderm, suggesting that there is a common program for chondrocyte differentiation in both axial and appendicular cartilage. Interestingly, BMPs only promote chondrogenesis of somitic mesoderm after previous exposure to Shh, either sustained or transient, suggesting that a major role of Shh in patterning the somite is to induce the 'maturation' of its BMP response, such that young somitic tissue responds to BMP signals by assuming lateral fates, and older sclerotomal tissue responds to these same signals by differentiating into cartilage.

\section{Results}

Shh is sufficient for in vitro chondrogenesis of presomitic mesoderm

Explants of presomitic mesoderm, equivalent in length to 2-3 somites, were prepared from 2-day-old (E2) chick embryos of 8-12 somites, embedded in collagen gels, and cultured for 5 days in a serum-free, semidefined medium. Under these culture conditions, the explants disperse 
rapidly into a proliferative mesenchyme and invade the collagen gel. In the absence of added factors or tissues, the explants fail to express myogenic or chondrogenic markers after extended culture (Fig. 1A, lane 1; data not shown). To determine whether Shh exposure suffices to elicit cartilage differentiation, we supplemented the medium with purified Shh amino-terminal peptide (Shh-N), to a final concentration of $500 \mathrm{ng} / \mathrm{ml}$. This dose of Shh-N is sufficient to induce motor neuron markers in intermediate neural plate explants, as described by Marti et al. (1995), but is two to fourfold below the minimal dose required to induce the floor plate marker HNF-3 $\beta$ (data not shown). Consistent with previous results (Fan et al. 1995; Münsterberg et al. 1995), psm explants exposed to Shh undergo considerably greater growth than untreated explants, and dramatically up-regulate expression of the early sclerotome marker Pax1 (Fig. 1A, lane 2). Shhtreated cultures also express the cartilage structural genes aggrecan and, at lower levels, collagen IX, whereas

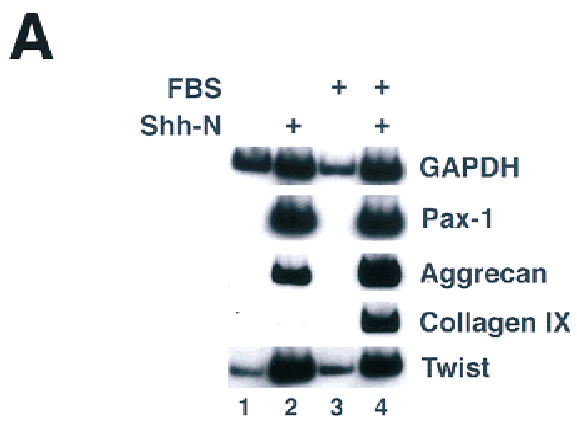

B

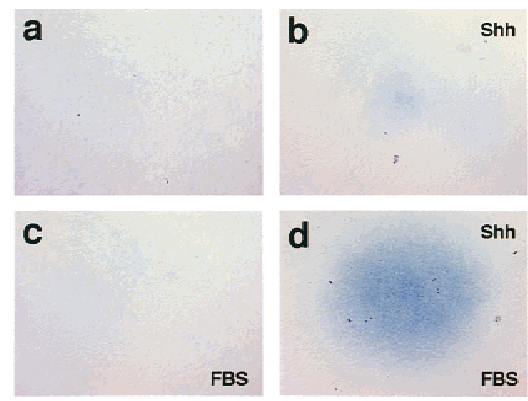

Figure 1. Exposure to Shh is sufficient for somitic chondrogenesis in vitro. (A) Presomitic mesoderm (psm) was dissected from 8- to 12-somite chick embryos ( stage 10) and cultured as indicated above each lane. Psm was cultured alone (lane 1), in the presence of $500 \mathrm{ng} / \mathrm{ml}$ soluble Shh-N (lane 2), in the presence of $1 \%$ fetal bovine serum (FBS; lane 3), or with both FBS and Shh-N (lane 4). After 5 days of culture, explants were processed for RT-PCR to analyze expression of the early sclerotomal marker Paxl, the chondrocyte markers aggrecan and collagen IX, and GAPDH and Twist as markers of viability. $(B)$ Cultures treated as above were fixed and stained with Alcian blue, a histochemical stain for chondrocytes. Cultures in $a$ and $c$ were cultured in the absence of Shh, those in $b$ and $d$ treated with Shh-N as above. The cultures in $c$ and $d$ were additionally treated with $1 \%$ FBS. untreated cultures lack expression of these genes (Fig. 1A, cf. lane 1 with lane 2). When stained with Alcian blue, a histochemical stain for cartilage matrix, faint staining is seen in the central regions of Shh-treated cultures, whereas no staining is visible in untreated controls (Fig. 1B, cf. a with b).

It is well-established that fetal bovine serum (FBS) augments the differentiation of chondrocytes cultured in vitro (Ellison et al. 1969; Glaser and Conrad 1984). Therefore, we examined the effects of adding FBS on cartilage development in explanted somitic tissue. Consistent with the observations of Stern and Hauschka (1995), the addition of $1 \%$ FBS, in the absence of Shh, led to decreased proliferation or increased cell death within the explants as indicated by a decline in GAPDH levels (Fig. 1A, cf. lane 1 with lane 3). However, FBS had little negative effect on the growth/survival of Shh-treated explants, and led to a considerable increase in both aggrecan and collagen IX expression (Fig. 1A, cf. lane 2 with lane 4), and in the elaboration of Alcian blue-staining matrix (Fig. 1B, cf. b with d). Whereas FBS significantly augmented the expression of aggrecan and collagen IX, it did not significantly affect the up-regulation of either Paxl or the basic helix-loop-helix (bHLH) protein Twist by Shh (Fig. 1, cf. lane 2 with lane 4). The prochondrogenic effects of FBS were not observed in the absence of Shh administration (Fig. 1A, lane 3; Fig. 1B,c), suggesting that FBS acts synergistically with Shh to promote chondrogenesis.

\section{Shh treatment induces cartilage markers}

in a temporally delayed fashion that correlates with expression of endogenous BMP genes

Expression of chondrocyte markers in somitic tissue in vivo occurs after a considerable lag period following sclerotome formation, and in a spatially limited domain within the sclerotome. In contrast to the sclerotomal marker Pax1, which is first detected in the ventral domain of epithelial somites in an E2 embryo (Johnson et al. 1994), aggrecan expression is first detectable by in situ hybridization at approximately Hamburger-Hamilton stage 24, in condensing perinotochordal mesenchyme (Fig. 2A,e). At this stage, aggrecan-expressing cells represent only a limited subset of the Paxl expression domain (Fig. 2A, cf. b with e). Collagen IX expression does not initiate until the appearance of morphologically recognizable chondrocytes and, as detected by in situ hybridization, is highly expressed in the stage 28 vertebral body (Fig. 2A,f; see also Swiderski and Solursh 1992). Interestingly, although collagen IX and aggrecan expression in stage 28 chick embryos is restricted to the definitive cartilage that surrounds the notochord, expression of Paxl is down-regulated in this same tissue (Fig. 2A, cf. c, f, and i).

To compare the relative time course of cartilage gene expression in vivo to that occurring in the in vitro somite culture system, we harvested Shh-treated and untreated psm after successive periods of culture in serumfree medium. Expression of the sclerotome marker Pax1 


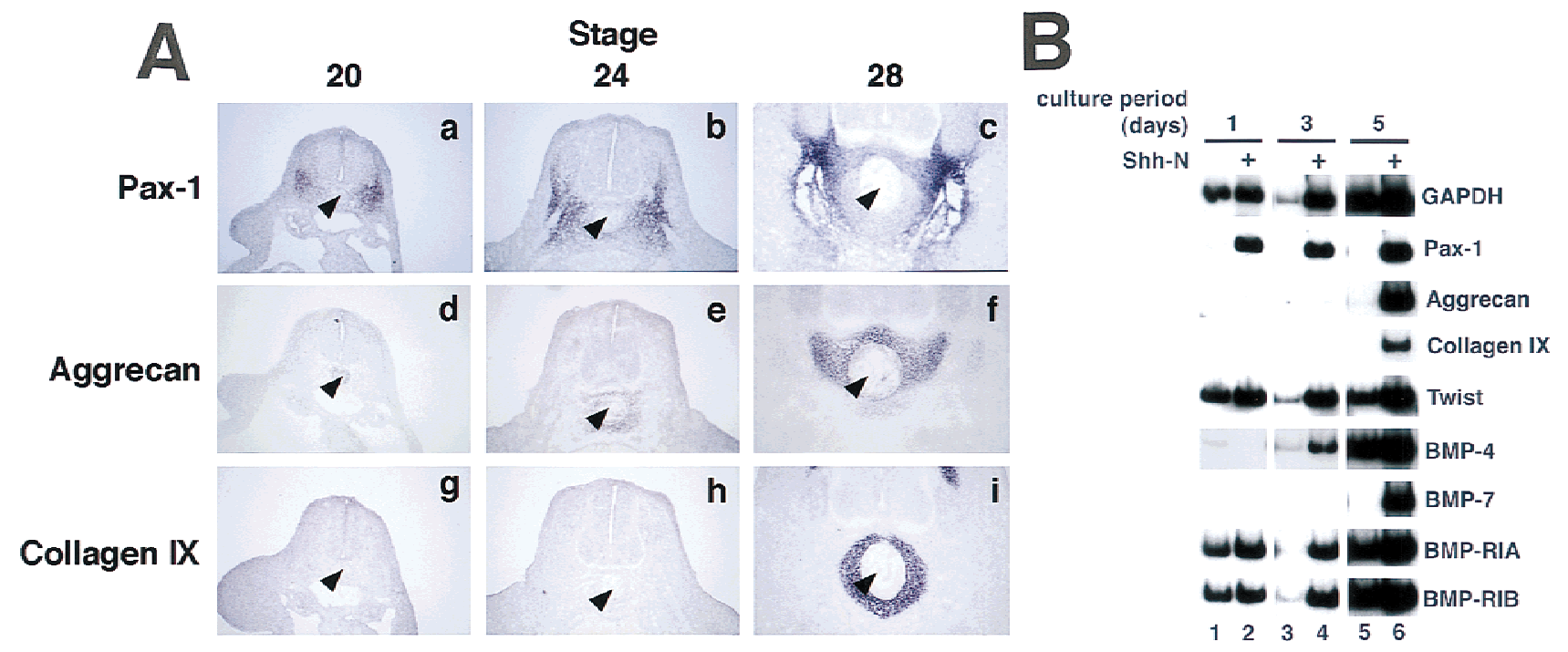

Figure 2. (A) Vertebral chondrogenesis is spatially and temporally restricted within the sclerotome. In situ hybridizations were performed on brachial-level sections of chick embryos, stages 20-28, with digoxigenin-labeled riboprobes to Pax1 $(a-c)$, aggrecan $(d-f)$, and collagen IX $(g-i)$. The notochord is indicated with an arrowhead. $(B)$ Cartilage genes are induced by Shh in a delayed fashion, concomitant with endogenous BMP genes. Cultures were harvested after 1,3, or 5 days of culture, in the absence (lanes 1,3,5) or presence (lanes 2,4,6) of Shh-N. RT-PCR was performed to detect sclerotomal and chondrocyte markers, as well as BMP4 and BMP7, and BMP receptors type IA and IB.

is induced to peak levels after only $24 \mathrm{hr}$ of exposure to Shh and remains high with extended culture (Fig. 2B, lanes 2,4,6). Pax 1 expression occurs at low levels at early time points in the absence of added Shh and subsequently decays in its continued absence (Fig. 2B, lanes $1,3,5)$, as has been observed previously in explanted mouse psm (Fan and Tessier-Lavigne 1994). This initial low-level expression of Paxl is not blocked by addition of anti-Shh antibodies (data not shown), suggesting that this initial low level expression is independent of $\mathrm{Shh}$ signaling. Paxl expression also initiates, but is not maintained, in mice lacking the Shh gene (Chiang et al. 1996); it is possible that the low-level expression of Paxl we see in explanted somites is regulated by a similar mechanism.

In contrast to the rapid up-regulation of Pax1 by Shh, induction of the cartilage markers aggrecan and collagen IX occur with considerably delayed kinetics. After Shh treatment, aggrecan transcripts are undetectable until the third day of culture (Fig. 2B, lane 4), although collagen IX first appears on day 5 (Fig. 2B, lane 6). Thus, the timing of chondrogenic gene expression in vitro recapitulates that observed during vertebra formation in vivo (Fig. 2A), and is consistent with the hypothesis that secondary signaling events may be required for differentiation of sclerotome. Indeed, the finding that Alcian blue staining in Shh-treated psm is restricted to the central regions of the explant (Fig. 1B,d), where cells are most dense and where paracrine signals might be most concentrated, also suggests that secondary signals may be required for chondrogenic differentiation in these cultures.

In the mouse, a number of BMP family members are expressed in and around the prechondrogenic sclero- tome, including BMP2, BMP5, and BMP7, which could potentially modulate the progress of chondrogenesis in this tissue (King et al. 1994; Lyons et al. 1995). We examined the timing of expression of these BMPs in the explanted somite cultures to determine whether BMPs might play a role in Shh-induced somitic chondrogenesis in vitro. Although BMP2 is not expressed at high levels in cultured chick psm (data not shown), BMP4 transcripts are readily detected by day 3 in untreated cultures and are boosted in the presence of Shh (Fig. 2B, lanes 3-6). In contrast, BMP7 expression appears to be strictly dependent on Shh exposure, initiating between days 3 and 4 only in Shh-treated cultures (Fig. 2B, lanes 3-6). Thus, at least two BMP family members, BMP4 and BMP7, are expressed during in vitro chondrogenesis of Shh-treated psm. It has been demonstrated by Niswander and colleagues that limb bud chondrogenesis requires signaling through the type IB BMP receptor (Zou et al. 1997). Expression of this receptor, as well as that of the type IA receptor (Fig. 2B), appears to be expressed constitutively within the explanted paraxial mesoderm in vitro. It is worth noting that although both BMP4 and the type IB and type IA receptors are apparently highly expressed in untreated psm, such cultures exhibit no chondrogenesis, suggesting that BMP signaling in the absence of Shh is insufficient to induce this differentiation program.

\section{BMP signaling is required for somitic chondrogenesis in vivo and in vitro}

We examined the expression of endogenous BMP and BMP receptor genes during formation of the vertebrae 
(Fig. 3A). As discussed above, collagen IX-expressing chondrocytes appear surrounding the notochord, in the prospective vertebral body, at approximately stage 28 of development (Fig. 3A, a). The type IB BMP receptor (BMP$\mathrm{RIB}$ ) is expressed in an overlapping pattern in perinotochordal cells at this stage, with lower levels of expression detectable in other somite-derived tissues (Fig. $3 \mathrm{~A}, \mathrm{~b})$; expression of this receptor in the prechondrogenic sclerotome initiates at considerably earlier time points, and can be first detected at stage 24 (data not shown). The relatively wide distribution of BMP-RIB transcripts is consistent with our observation that this receptor is expressed in cultured paraxial mesoderm in the absence of Shh treatment (Fig. 2B). BMP7 expression in paraxial mesoderm is first detected by in situ hybridization in the perinotochordal sclerotome in stage 28 chick embryos (Fig. 3A,c), consistent with its late, Shh-dependent expression in vitro (Fig. 2B). In explanted paraxial mesoderm, BMP4 is expressed independently of exposure to Shh (Fig. 2B). In vivo, BMP4 is widely expressed at stage 28 , in both somitic and nonsomitic tissues (Fig. 3A,d). BMP4 expression as detected by in situ hybridization was only obtained with an antisense BMP4 probe (Fig. $3 \mathrm{~A}, \mathrm{~d}$ ) and was not detected with a BMP4 sense probe (Fig. $3 \mathrm{~A}, \mathrm{e})$, suggesting that the widespread in situ hybridization signal represents bona fide sense BMP4 transcripts. In summary, these expression patterns indicate that vertebral precursor tissue expresses the functionally relevant type IB BMP receptor, and is exposed to at least two BMP family members, BMP7 and BMP4, during early phases of chondrogenesis.

To examine directly the functional role of BMPs in somitic chondrogenesis, we took advantage of recent work demonstrating the utility of the secreted protein Noggin as a pharmacological reagent to interfere with BMP signaling (Zimmerman et al. 1996; Hirsinger et al. 1997; Liem et al. 1997; Marcelle et al. 1997; Capdevila and Johnson 1998; McMahon et al. 1998; Reshef et al. 1998). Noggin binds to BMP2 and BMP4 and inhibits their interactions with their cognate receptors; at higher concentrations, Noggin also inhibits BMP7 (Zimmerman et al. 1996). Misexpression of chicken Noggin, through a retroviral vehicle (RCAS-Noggin), has been shown previously to abolish limb-bud chondrogenesis in vivo (Capdevila and Johnson 1998), indicating that BMPs are necessary for appendicular cartilage formation. To explore whether BMPs are similarly required for formation of axial cartilage we examined the effects of ectopic expression of RCAS-Noggin on axial chondrogenesis. The paraxial mesoderm running from forelimb to hindlimb levels on one side of an E3 embryo was injected with an RCAS-Noggin virus and allowed to develop until E8, when significant vertebral chondrogenesis has occurred in normal embryos. Control embryos were infected with a virus- driving expression of the human placental alkaline phosphatase gene (RCAS-AP). We observed that $100 \%$ of embryos infected with RCASNoggin displayed severe skeletal deficiencies on their infected sides, including truncation and loss of vertebrae, ribs, and limb girdles (Fig. $3 \mathrm{~B}, \mathrm{a} ; n=8$ of 8 surviving embryos). In contrast, no skeletal abnormalities were seen in RCAS-AP-infected embryos ( $n=0$ of 9 ; data not shown). Thus, BMP signaling appears to be an obligate step in the formation of both the axial and appendicular skeletons. In contrast to a gross deficiency of Alcian blue-staining cartilage, expression of the early sclerotome marker Paxl was not significantly affected by Noggin misexpression (Fig. 3B,b,c), suggesting that the requirement for BMPs lies downstream of the formation or maintenance of the sclerotome.

To test the involvement of BMP family members in Shh-induced chondrogenesis in vitro, we supplemented psm explant cultures with medium conditioned by Noggin-expressing cells. Whereas explants treated with Shh in the absence of serum express aggrecan strongly and collagen IX only weakly, both of these responses are essentially abolished when explants are treated with Noggin-conditioned medium (Fig. 4A, cf. lane 1 with lane 2).
A
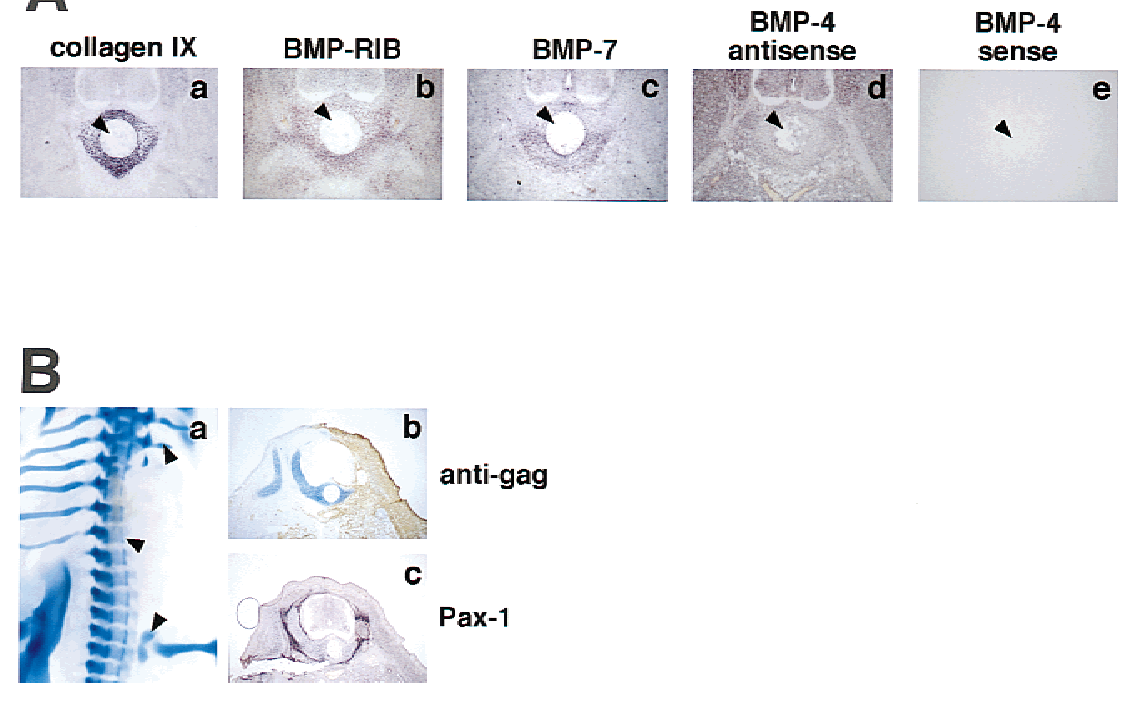

Figure 3. Expression and function of BMP signaling components in vivo. $(A)$ Section in situ hybridizations were performed, at brachial levels, with digoxigenin-labeled riboprobes to collagen IX $(a)$, BMP-RIB $(b)$, BMP7 $(c)$, and BMP4 (antisense probe shown in $d$, sense in $e$ ). In each panel, the notochord is indicated with an arrowhead. (B) Somites of E3 chick embryos were injected unilaterally with RCAS-Noggin virus, and analyzed on E8. $a$ shows alcian blue staining of a typical infected embryo; cartilage deletions are indicated by arrowheads. $(b, c)$ Adjacent, post-thoracic-level sections from an infected embryo, analyzed for cartilage (blue) and viral gag protein (brown; $b$ ), or Pax1 mRNA (purple, $c$ ). 
A

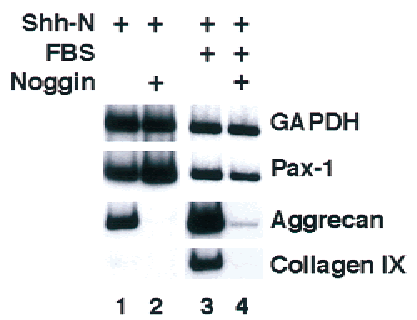

B

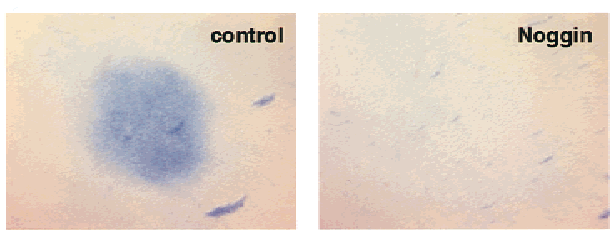

Figure 4. In vitro chondrogenesis of Shh-treated psm is dependent specifically on BMP signaling. $(A)$ Explants were cultured in the presence of Shh-N and in the absence (lanes 1,2) or presence (lanes 3,4) of 1\% FBS. Where indicated (lanes 2,4), Nogginconditioned medium was added on the second day of culture to inhibit BMP signals. After 5 days, cultures were analyzed by RT-PCR for the sclerotomal marker Paxl and the chondrocyte markers aggrecan and collagen IX. $(B)$ Explants cultured in the presence of Shh-N and 1\% FBS were treated with control (left) or Noggin-conditioned medium (right), and stained with Alcian blue after 5 days.

In the presence of $1 \%$ FBS, Shh-treated explants express higher levels of both of these cartilage markers; under these culture conditions, treatment with Noggin similarly inhibits expression of these genes (Fig. 4A, cf. lane 3 with lane 4). In addition, Noggin-treated explants are also inhibited completely from elaborating Alcian bluestaining matrix (Fig. 4B). As seen in vivo, treatment of Shh-induced cultures with Noggin specifically inhibits cartilage differentiation, without affecting more proximal responses to Shh such as proliferation (as evidenced by culture size and GAPDH levels) or Paxl gene expression (Fig. 4). Thus, blockade of BMP signaling can uncouple the effects of Shh on cell proliferation and induction of Paxl gene expression from the subsequent induction of chondrogenic differentiation markers, suggesting that the positive effect of BMPs on chondrogenesis is exerted at a relatively late stage of sclerotome development.

Previous exposure to Shh changes the competence of somitic cells to respond to BMP signals

Work both in vivo and in vitro has clearly demonstrated that exposure of psm to BMPs will inhibit the elaboration of most, if not all, somitic lineages, including sclerotome (Hirsinger et al. 1997; Tonegawa et al. 1997; Mc-
Mahon et al. 1998; Reshef et al. 1998). This stands in contrast to our observation that BMP signaling is necessary for sclerotome chondrogenesis. These contradictory results may be reconciled by the fact that the manipulations performed in previous work have involved the immediate exposure of presomitic mesoderm or recently formed somites to BMPs, whereas in our system, as in vivo, endogenous BMP family members are not expressed until after formation of sclerotome. At such a later time, the competence of the somitic cells to respond to BMP signaling might have changed. We sought to determine whether such a change in competence does in fact occur in cultured psm, and, if so, whether it occurs as the result of a timing mechanism intrinsic to the somite, or as a consequence of exposure to Shh.

Psm explants were cultured in the absence or presence of exogenous Shh, and recombinant BMP4 was added to a final concentration of $100 \mathrm{ng} / \mathrm{ml}$ either at the beginning of the culture period or after 2 days of culture (exposure periods to Shh and BMP4 is schematically outlined in Fig. 5A). Cultures were maintained for a total of 5 days. As previously demonstrated by Reshef et al. (1998), BMP4 added alone at the beginning of the culture period induces the lateral plate marker GATA-4, but fails to induce any cartilage markers (Fig. 5B, lane 2). Whereas Shh induces high levels of Pax1, and low levels of aggrecan (Fig. 5B, lane 3), simultaneous addition of Shh and BMP4 blocks expression of both these genes, and instead induces expression of the lateral plate marker GATA-4 (Fig. 5B, lane 4). Thus, as seen in vivo (Hirsinger et al. 1997; Tonegawa et al. 1997), administration of BMP4 to psm in vitro negates the sclerotomeinducing properties of Shh, and elicits expression of lateral plate mesoderm markers (Tonegawa et al. 1997). In addition, it appears that BMP4 negatively regulates proliferation or survival of cultured psm (Fig. 5B, cf. GAPDH levels between lanes 1 and 2); this effect is blocked by Shh (Fig. 5B, lanes 3,4), suggesting that BMP4 does not simply abolish Shh responsiveness. If BMP4 is added after the psm has been maintained in culture for 2 days, it remains capable of inducing robust expression of GATA-4 (Fig. 5B, lane 5). Although late exposure to BMP4 in the absence of Shh occasionally activates trace levels of aggrecan expression (Fig. 5B, lane 5), it never produces detectable Alcian blue-staining chondrocytes (Fig. 5C,b). In striking contrast, explants exposed to Shh for 2 days before addition of BMP4 exhibit remarkably robust chondrogenesis, as assessed by significantly increased expression of aggrecan and collagen IX (Fig. 5B, lane 6) and dramatically increased differentiation of Alcian blue-staining chondrocytes (Fig. 5C,d). Importantly, previous treatment with Shh abolishes the induction of GATA-4 by BMP4 (Fig. 5B, cf. lane 5 with lane 6). We have obtained essentially identical results with BMP7 protein (data not shown). We conclude from these results that Shh alters the response of the psm to BMP signals, changing the consequence of BMP signaling from lateralization to chondrogenesis. In the absence of exposure to Shh, somites retain their initial 'immature' BMP response and can, in part, be reprogrammed into lateral 


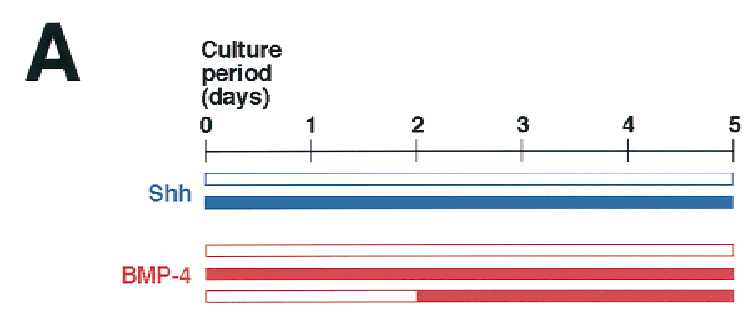

B

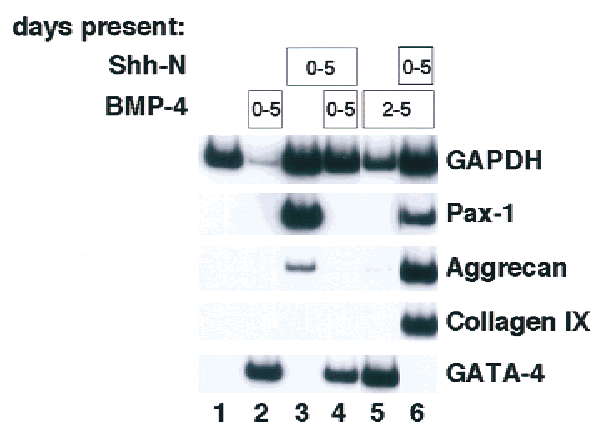

C

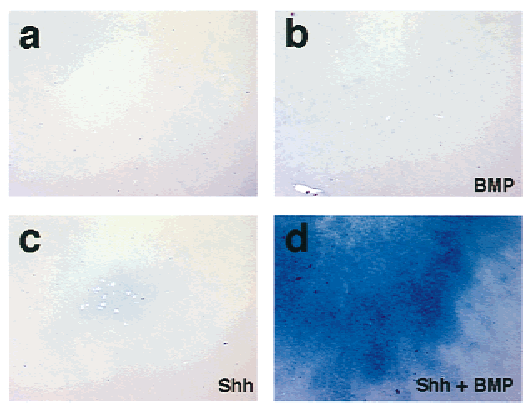

Figure 5. Does the response to BMP signaling change with time or with exposure to Shh? $(A)$ Schematic diagram of the experiments shown below. Explants were cultured in the absence or presence of Shh (blue), and BMP4 (red) was added at the start of the culture period, after 2 days of culture, or not at all. (B) Exposure to Shh alters the somitic response to exogenous BMP. Cultures were treated with $500 \mathrm{ng} / \mathrm{ml}$ Shh-N and 100 $\mathrm{ng} / \mathrm{ml} \mathrm{BMP} 4$ for the periods indicated in the boxes, and harvested for RT-PCR after 5 days of culture, to analyze expression of Paxl, aggrecan, collagen IX, and the lateral plate marker GATA-4. $(C)$ Cultures treated as above were fixed and stained for Alcian blue. Explants in $c$ and $d$ were treated with Shh-N for the entire culture period. Those in $b$ and $d$ were treated with BMP4 starting on the second day of culture.

fates, whereas, after exposure to Shh, BMPs promote the differentiation of sclerotomal cells into cartilage.

Transient exposure to Shh is sufficient to alter the response to BMP signals

In the above experiment, explants were maintained in the presence of Shh during the entire course of culture; in vivo, however, sclerotomal cells must migrate away from the ventral midline sources of Shh to produce the cartilaginous rudiments of the neural arches and spinous process. In the course of this migration, the dorsally situated sclerotomal derivatives down-regulate expression of Pax1 (see, e.g., Fig. 2A,a,b). Because maintenance of Pax1 gene expression requires continued Shh signaling (Münsterberg et al. 1995), this result suggests that migratory sclerotomal cells are exposed only transiently to Shh. We sought to examine whether transient exposure to Shh is sufficient to change the response of psm to subsequent BMP signaling. psm explants were exposed to Shh for either the entire 5-day culture period or for only the first 2 days of culture; in the latter case, the explants were washed repeatedly with medium lacking Shh, and blocking anti-Shh antibody added to inhibit the activity of any residual Shh. (Levels of anti-Shh antibody were used such that administration of this antibody at the beginning of the culture period completely blocked a response to Shh; data not shown.) Cultures were then maintained for an additional 3 days in either the absence or presence of $100 \mathrm{ng} / \mathrm{ml} \mathrm{BMP} 4$.

After 2 days of exposure of psm to Shh, Pax1 is expressed; however, expression of the cartilage markers aggrecan and collagen IX is not yet detectable (see Fig. 2B; data not shown). When Shh is removed and anti-Shh added during the subsequent 3 days of culture, the explants lose expression of Paxl and fail to express the cartilage marker genes (Fig. 6B, lane 3). The expression of Gli, another Shh target gene in the somite (Marigo et al. 1996; Borycki et al. 1998), similarly decays on removal of Shh protein (Fig. 6B, lane 3). Remarkably, however, explants from which Shh has been removed respond to exogenous BMP4 essentially as robustly as those exposed to continual Shh (Fig. 6B, cf. lane 5 with lane 6). Thus, although neither transient exposure to Shh (Fig. 6B, lane 3) nor late exposure to BMP4 alone (Fig. 6B, lane 4) is sufficient for chondrogenesis, the combination triggers dramatic chondrocyte differentiation (Fig. 6B, lane 6). This differentiation occurs in the absence of either maintained Pax1 expression or high-level Gli expression (Fig. $6 \mathrm{~B}$, lane 6), suggesting that it occurs independently of maintained Shh signaling. We interpret these results to suggest that only a limited exposure to Shh is required to induce maturation of the BMP response, and that maintained Shh signaling is not necessary for differentiation of somitic cartilage.

\section{Discussion}

Previous work in the chick and the mouse has established a critical role for the ventral midline structures in the induction of vertebral cartilage (Watterson et al. 1954; Grobstein and Holtzer 1955; Hall 1977; Pourquié et al. 1993; Monsoro-Burq et al. 1994). More recent studies demonstrate that the secreted signaling molecule Shh, which is expressed by these inducing tissues, is sufficient to induce the first steps of somitic chondrogenesis, as characterized by expression of the sclerotome marker Pax1 (Fan and Tessier-Lavigne 1994; Johnson et 


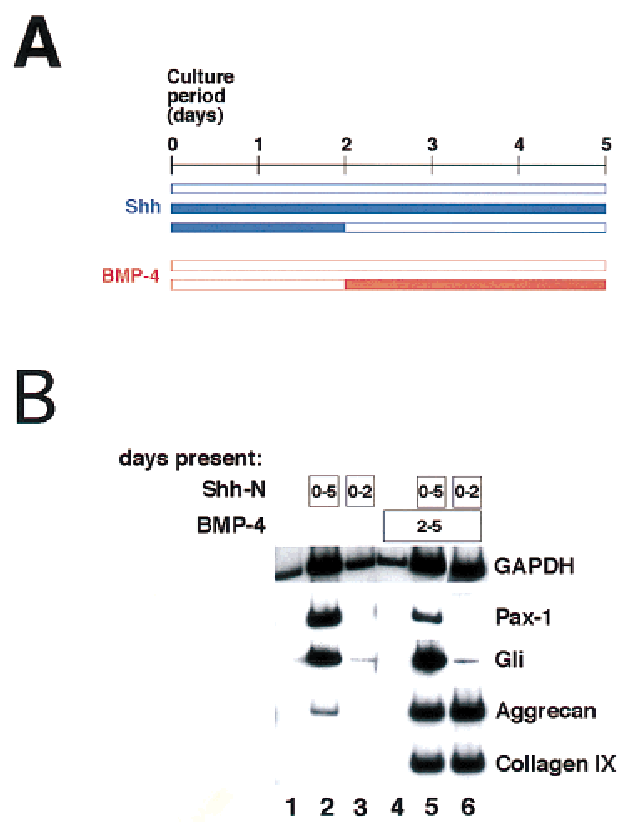

Figure 6. Transient exposure to Shh is sufficient to change the competence to respond to BMP signals. (A) Schematic diagram of the experiment. Shh (blue) was administered at the onset of culture; in some explants it was removed subsequently on the second day of culture and a blocking anti-Shh antibody was added at this time. BMP4 (red) was added on the second day of culture, as previously. (B) Explants were exposed to Shh and BMP4 for the culture periods indicated in the boxes, and harvested for RT-PCR on the fifth day of culture.

al. 1994; Fan et al. 1995). We show here that exogenously added Shh is also sufficient to initiate the entire chondrogenic program in explanted chick presomitic mesoderm. However, chondrogenesis per se appears to represent a distinct step from sclerotome formation, based on the findings that it occurs only after a temporal lag following the initial response to Shh, and depends entirely on signaling by a second family of secreted factors, the BMPs. Although work in the limb bud clearly implicates BMP signaling in chondrogenesis, previous studies in the somite suggested that BMPs act primarily as lateralizing factors (Pourqué et al. 1996; Tonegawa et al. 1997;
Reshef et al. 1998). We resolve this paradox by demonstrating that a major and critical activity of Shh is to alter the response of somitic mesoderm to BMP signaling. Previous Shh treatment of somitic mesoderm inhibits activation of lateral plate markers in this tissue and induces a chondrogenic response to subsequent BMP signaling (Fig. 7A). The timing of exposure of somitic tissue to Shh and BMP signals is crucial in modulating the type of response that is elicited. Whereas previous exposure of presomitic tissue to Shh followed by subsequent BMP signals elicits chondrogenesis, simultaneous exposure to both these signals does not support chondrogenesis and instead induces lateral plate gene expression. On the basis of these results, and those obtained in vivo, we propose that sequential exposure to Shh and BMPs are crucial events in the development of the vertebrae.

\section{Relationships between the early and late patterning of the sclerotome}

Both early and late aspects of sclerotome development are eliminated in embryos that are genetically or surgically deprived of the ventral midline sources of Shh (Watterson et al. 1954; Dietrich et al. 1993, 1997; Goulding et al. 1993; Monsoro-Burq et al. 1994; Ebensperger et al. 1995; Chiang et al. 1996). Maintained expression of early markers, such as Pax1, is lost in the absence of Shh signals, and subsequent formation of the vertebrae fails as well. Somite rotation experiments (Aoyama and Asamoto 1988; Christ et al. 1992), as well as in vitro analyses (Fan and Tessier-Lavigne 1994; Fan et al. 1995; Münsterberg et al. 1995), support the notion that Shh signals sent from the ventral midline tissues can act instructively on the undetermined presomitic mesoderm both dorsally, to inhibit dermomyotome, and ventrally, to induce both myotome (Johnson et al. 1994; Münsterberg et al. 1995; Borycki et al. 1998) and sclerotome (Fan and Tessier-Lavigne 1994; Johnson et al. 1994; Fan et al. 1995). Our data suggest that a key function of this instructive signal is to change the somitic response to BMP signals. In the absence of a Shh signal in vitro, exposure to $100 \mathrm{ng} / \mathrm{ml} \mathrm{BMP} 4$ induces lateral plate gene expression in cultured psm. After exposure of this tissue to Shh for periods as brief as $24 \mathrm{hr}$ (data not shown), this response to

Figure 7. A two-step model for generation of axial and appendicular cartilage. $(A) \mathrm{Na}$ ivepresomitic mesoderm (psm) responds to BMPs by assuming lateral plate fates (red); following its conversion into sclerotome (blue) by Shh, these cells respond to the same BMP signal by differentiating into chondrocytes (purple). (B) In the early limb bud, exogenous BMPs induce apoptosis (red); it is likely that endogenous BMPs also play a patterning role at this stage. As the
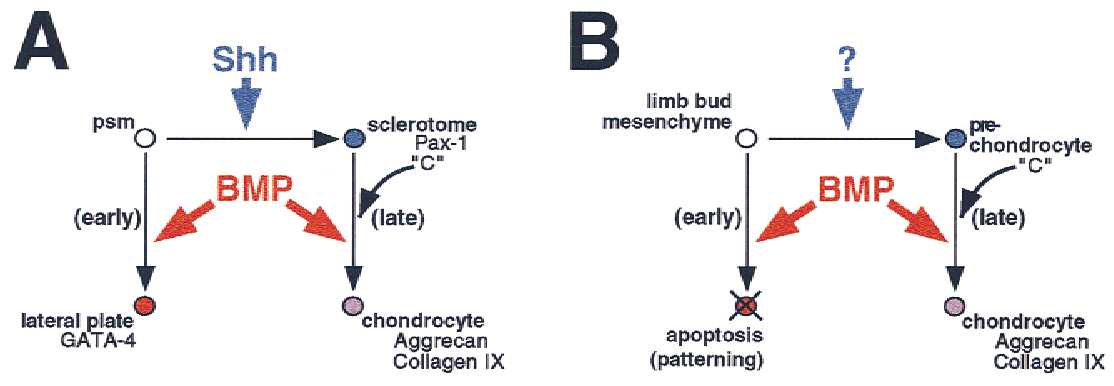
limb bud matures, BMPs are necessary and sufficient to convert prechondrocytes (blue) into chondrocytes (purple), as in the somite. The scapula and ribs, which develop independently of Shh from the lateral somite, may follow a pathway similar to that of the limb bud. It is suggested that in all of these tissues a hypothetical factor ' $\mathrm{C}$ ' acts to promote the later, chondrogenic response to BMP signaling. 
BMP administration is blocked and the competence to initiate chondrogenesis in response to subsequent BMP signals is induced. It is possible that induction of sclerotome by Shh reflects in part an inhibition of the lateralizing function of BMP4, as McMahon et al. (1998) have shown that high concentrations of the BMP inhibitor Noggin can induce low levels of Paxl mRNA in mouse psm explants, independently of Shh signaling. It should be noted, however, that the level of Pax1 expression obtained under these circumstances is considerably lower than that induced by Shh, and that, in vivo, sustained Paxl expression depends entirely on Shh (Chiang et al. 1996).

In contrast to its early inhibitory function, a later phase of BMP signaling is required to promote chondrogenesis, as pharmacological application of Noggin, in vivo and in vitro, inhibits cartilage differentiation without affecting the earlier Shh-dependent formation of sclerotome. Conversely, mice lacking the Noggin gene exhibit fusions between vertebral bodies, as well as thickened and fused ribs, suggesting that increased levels of active BMPs can promote chondrogenesis of the axial skeleton (McMahon et al. 1998). Several BMP family members are expressed in and around the sclerotome during its differentiation, as well as in neighboring tissues such as the dermomyotome and roof plate (Fig. 3A; see also King et al. 1994; Liem et al. 1995, 1997; Lyons et al. 1995; Monsoro-Burq et al. 1996; Capdevila et al. 1998). It is possible that localized expression of BMPs by tissues surrounding the sclerotome directs the spatial sculpting of the spinal column, and ensures proper morphogenetic integration of muscles and nerve with the vertebrae.

Recently, it has been found that Shh can act as a survival factor for somitic lineages (Teillet et al. 1998). It is, however, unlikely that a selective rescue from cell death can account for the patterning activities of the notochord and floor plate, as essentially no cell death is observed in vivo during the period in which determined myotomal and sclerotomal cells begin to arise in the uncommitted paraxial mesoderm (Williams and Ordahl 1997; Dockter and Ordahl 1998), and later cell death is restricted to a small subpopulation of the sclerotome (Sanders 1997). Shh induces the survival/proliferation of cultured psm (Fan and Tessier-Lavigne 1994; L.C. Murtaugh, unpubl.), and it remains a formal possibility that the properties we ascribe to an instructive Shh signal may represent the clonal expansion of chondrogenic cells. However, such a model cannot account for the inhibition of lateralization that we see in Shh-treated explants, unless Shh also eliminates selectively those cells that differentiate into lateral plate in response to a BMP signal.

Does all somite chondrogenesis follow the same signals?

In addition to vertebrae, the somites give rise to ribs at thoracic levels and to the scapula at brachial levels (Chevallier 1975, 1977). The anteroposterior (A-P) fate of the paraxial mesoderm is determined considerably be- fore segmentation, as revealed by heterotopic grafting experiments (Kieny et al. 1972; Chevallier 1975, 1977). As noted above, embryos genetically or surgically deprived of Shh fail to form a vertebral column and lack proximal ribs; however, distal ribs and scapulae are still formed in such embryos (Chiang et al. 1996; Teillet et al. 1998). Thus, at restricted levels along the A-P axis, somites exhibit a capacity for Shh-independent chondrogenesis. Kenny-Mobbs and Thorogood (1987) found that brachial somites, which are fated to produce scapula, were able to chondrify in vitro in the absence of neural tube and notochord. We have also obtained preliminary evidence that brachial somites specifically exhibit a chondrogenic response to BMP4 in the absence of added Shh (data not shown). Interestingly, fate mapping studies show that the Shh-independent skeletal derivatives of these somites (i.e., scapula and distal ribs) derive from their lateral halves, whereas the Shh-dependent vertebrae and proximal ribs arise medially (Ordahl and Douarin 1992; B. Christ, pers. comm.). More recently, the fate map of the ribs has been further refined, and it has been shown that the distal ribs derive from the lateral dermomyotome, rather than the sclerotome (Kato and Aoyama 1998). Thus, the maintenance of lateral somite-derived cartilage in Shh-deficient mice suggests that signals other than Shh may confer competence specifically on lateral somitic tissue to initiate the chondrogenic program.

In addition to the lateral axial skeleton, Le Douarin and co-workers have proposed that the dorsal-most portion of the vertebra itself, the spinous process, develops according to a distinct molecular program from the more ventral neural arches and vertebral body (Monsoro-Burq et al. 1994, 1996). They propose that the spinous process arises from Msx1/Msx2-expressing mesenchyme that migrates dorsal to the neural tube, and that this region of the vertebra is induced specifically by BMPs deriving from the roof plate. In support of this, Monsoro-Burq et al. found that implantation of BMP-expressing cells above the dorsal surface of the neural tube in E2 or E3 chick embryos, induced both ectopic Msx gene expression and the formation of enlarged and fused spinous processes (Monsoro-Burq et al. 1996). These researchers also observed that grafts of BMP2- or BMP4-expressing cells located between the somites and the axial structures in E2 chick embryos led to a unilateral deletion of the vertebrae (Monsoro-Burq et al. 1996). On the basis of these findings, these workers suggested that the dorsal spinous process arises separately from the ventrolateral structures of the vertebra, and that the former vertebral structure is uniquely induced by BMPs (Monsoro-Burq et al. 1996). In light of our own results and those of other investigators, we propose that implantation of BMP-expressing cells between the neural tube and somite blocked formation of vertebrae because ectopic expression of high levels of BMPs directly adjacent to recently formed immature somitic tissue inhibits all sclerotome development (Monsoro-Burq et al. 1996; Hirsinger et al. 1997; Tonegawa et al. 1997) by inducing this tissue to develop as lateral plate tissue (Tonegawa et al. 1997). In 
contrast, implantation of BMP-expressing cells dorsal to the neural tube, a region not encountered by somitic cells until considerably after sclerotome induction (Christ and Wilting 1992), acts on cells that have already encountered Shh and consequently have altered their BMP responsiveness accordingly. In this case, ectopic BMP treatment fails to induce conversion of somitic tissue to lateral plate tissue but rather promotes local cartilage differentiation.

\section{A unified program for formation of the endochondrial skeleton}

Our results, when integrated with those obtained in studies of the limb bud, support a single model to explain development of diverse cartilage elements (Fig. 7). The first step in this process is the specification of committed cartilage precursor cells (blue), which is mediated by ventral midline-derived Shh in the case of the medial presomitic mesoderm (Fig. 7A), and mediated by unknown signals or intrinsic cues in the case of early limb bud mesenchyme (Fig. 7B). Before this specification process, BMPs act on these tissues to promote lateralization and apoptosis, respectively (red). As an essential part of maturing a chondrogenic potency, cells alter their response to BMP signaling; therefore, a later BMP signal promotes differentiation into chondrocytes (purple).

It is interesting to consider what controls how a cell will respond to a given BMP signal. In the limb bud, the type IA and IB BMP receptors have been shown to affect differentially chondrogenesis, with only the type IB receptor being necessary for the initial formation of chondrocytes (Zou et al. 1997). However, the parameters that modulate whether a BMP signal effects either an apoptotic or a chondrogenic response must occur downstream of the receptor, because activation of the type IB receptor is both necessary and sufficient for apoptosis in the early limb bud (Zou et al. 1997). Similarly, BMP treatment of psm only elicits lateral plate gene expression and fails to induce chondrogenesis, although this tissue expresses both the type IA and type IB receptors. Together these findings suggest that in both somites and limb bud, the particular response to a BMP signal is not designated by the identity of the type I receptor, but rather by elements in the signal transduction pathway that lie downstream of the receptor. We speculate that Shh in the medial somite and a distinct signal in the lateral somite and limb bud alter the BMP responsiveness of their target tissues by inducing a common factor or factors, labeled $\mathrm{C}$ in Figure 7, that cooperates with the BMP signal transduction pathway to modulate its transcriptional output. This factor could be a DNA-binding partner for Smad proteins that mediate a BMP signal (Kretzschmar and Massagué, 1998), analogous to the FAST-1 Forkhead protein that acts downstream of activin signaling (Chen et al. 1996), or it could act upstream of or in parallel with such a protein. A strong prediction of our model is that the $\mathrm{C}$ factors would be expressed in all cell lineages that display a chondrogenic response to BMP signaling. Current work in the labora- tory is focused on identifying such competence factors that mediate a chondrogenic response to BMP signaling.

\section{Materials and methods}

Biological materials

Bacterially produced Shh-N protein (fragment N3) was produced as described previously (Marti et al. 1995). BMP proteins were the generous gift of the Genetics Institute (Cambridge, MA). 5E1 mouse anti-Shh hybridoma (Ericson et al. 1996) was purchased from the Developmental Studies Hybridoma Bank [maintained by University of Iowa, supported by The National Institute of Child Health and Development (NICHD)], and antibody purified as described (Ericson et al. 1996). Noggin-conditioned medium was harvested from CHO B3 cells, engineered to express Xenopus Noggin (Lamb et al. 1993), the kind gift of Richard Harland (University of California, Berkeley). Cells were grown to confluence in serum-containing medium, then allowed to condition defined SFM-II medium (GIBCO) for 3 days; aliquots of medium were stored at $-80^{\circ} \mathrm{C}$. Control cultures were incubated with medium conditioned by nontransfected $\left(\mathrm{dhfr}^{-}\right)$ $\mathrm{CHO}$ cells.

\section{Explant culture}

Fertilized chick eggs (Spafas) were incubated at $37.5^{\circ} \mathrm{C}$, and embryos were staged according to Hamburger and Hamilton (1951). Tissues were isolated and embedded in collagen gels as described in Münsterberg et al. (1995). We used a semi-defined, serum-free culture medium, modified from that of Stern and Hauschka (1995), consisting of Ham's F-10 medium (GIBCO) with the following additives: $0.8 \mathrm{mM} \mathrm{CaCl}_{2}, 30 \mathrm{~nm}$ sodium selenite, $100 \mu \mathrm{M}$ putrescine, $100 \mu \mathrm{g} / \mathrm{ml}$ conalbumin, $6 \mu \mathrm{g} / \mathrm{ml}$ in sulin, $2 \%$ chick embryo extract (GIBCO), and $1 \mathrm{ng} / \mathrm{ml} \mathrm{bFGF}$, with $1 \%$ Pen/Strep solution to retard bacterial growth. Explants were refed on the second day of culture, and harvested on the fifth day, unless noted otherwise. When Noggin or control-conditioned medium was used, explants were refed on the second day with a 1:1 mixture of double-strength culture medium and appropriate conditioned medium.

\section{RT-PCR analysis}

RT-PCR analysis was performed as described by Münsterberg and Lassar (1995). After production of cDNA by reverse transcriptase, single PCR reactions were performed with appropriate primer pairs, using radiolabeled $\left[\alpha^{32} \mathrm{P}\right] \mathrm{dCTP}$. Appropriate controls were performed to ensure that amplifications were roughly linear, and dependent on addition of reverse transcriptase. Primers used were as described in Münsterberg et al. (1995), Reshef et al. (1998), and as follows: aggrecan (Li et al. 1993), 5' -CCTGCCTGACCTCTTTGC, 3' -TGGGGAGGAGGGCAACAT (278 bp); collagen IX (Vasios et al. 1988), 5' -CAGGACTTATGACAGGGAAC, ${ }^{\prime}$ '-TCTTGATTGTTGCTGGTAGG (174 bp); BMP4 (Francis et al. 1994), 5'-AAGAAAGTCGCAGAGCTTCAGGGA, 3'-TCCACCTGCTCCCGGTACAGCCGC (404 bp); BMP7 (Houston et al. 1994), 5'-AGAATCCCAGAGGGGGAAGCA， 3'-GCTGCTGTTCTCTGCGATGTT (486 bp); BMP-RIA (Kawakami et al. 1996), 5'-ATTTACAGCCGACATTACCA, 3'-ACCATATCGTCCCTTTCCAA (344 bp); BMP-RIB (Kawakami et al. 1996), 5' -CAGGTACAAGCGGCAAGAAG, 3'CCTTTTCGCCACGCCACTTT (239 bp); Gli (Marigo et al. 1996), 5'-AAGCATCAGAACCGCACCCACTC, 3'-CCACCCGTGTTGCCCGTCATCTC (389 bp). 


\section{In situ hybridization}

In situ hybridization was performed following a protocol of Naomi Fukai (pers. comm.), modified slightly. Full details are available upon request. Briefly, chick embryos were fixed overnight with $4 \%$ parafomaldehyde (PFA) in PBS, cyroprotected in sucrose/PBS, and embedded in OCT. Frozen sections $(14 \mu \mathrm{m})$ were subjected to acid hydrolysis $(0.2 \mathrm{~N} \mathrm{HCl}, 15 \mathrm{~min})$, proteinase $\mathrm{K}$ treatment $(3 \mu \mathrm{g} / \mathrm{ml}$ in PBS, $15 \mathrm{~min})$, postfixation (4\% PFA, 5 $\mathrm{min})$, and acetylation ( $0.25 \%$ acetic acid, $15 \mathrm{~min})$. Each of these steps was followed by two 5-min washes with PBS. After the last PBS wash, slides were rinsed with $\mathrm{dH}_{2} \mathrm{O}$ and air-dried, before a 2-hr prehybridization step, at $65^{\circ} \mathrm{C}$, in hybridization solution [50\% formamide, $10 \mathrm{~mm}$ Tris (pH 7.6), $200 \mu \mathrm{g} / \mathrm{ml}$ Torula yeast RNA, $1 \times$ Denhardt's solution, $10 \%$ dextran sulfate, 600 mM NaCl, $0.25 \%$ SDS, 1 mM EDTA (pH 8.0)]. Hybridization with digoxygenin-labeled cRNA probes was performed overnight at $65^{\circ} \mathrm{C}$. Posthybridization, slides were rinsed briefly in $5 \times$ SSC at $65^{\circ} \mathrm{C}$, washed with $1 \times$ SSC, $50 \%$ formamide $\left(65^{\circ} \mathrm{C}, 30\right.$ min), subjected to RNase A digestion to reduce nonspecific hybridization, and washed at increasing stringency with SSC buffers (final wash at $55^{\circ} \mathrm{C}$ with $0.2 \times \mathrm{SSC}$ ). Bound probe was detected with alkaline phosphatase-conjugated anti-DIG antibodies (Boeringer-Mannheim), and NBT-BCIP substrate. The Pax1 in situ hybridization probe is described in Ebensperger et al. (1995), and was the kind gift of Haruhiko Koseki (Chiba University School of Medicine). The aggrecan probe was generated by cloning the 278-bp aggrecan RT-PCR product (see above) into pBluescript II KS(+) (Stratagene). The collagen IX probe was generated by cloning the 412-bp EcoRI insert of IN321 (Vasios et al. 1988; the kind gift of Ichiro Nishimura, University of California, Los Angeles), encoding the amino-terminal NC4 domain of chick $\alpha 1$ (IX) collagen, into pBluescript II KS(+). The BMP4 and BMP7 probes are described in Liem et al. $(1995,1997)$, and were the generous gift of Tom Jessell (Columbia University, New York, NY). The BMP-RIB probe is described in Zou et al. (1997), and was graciously provided by Lee Niswander (Memorial Sloan-Kettering Cancer Center, New York, NY).

\section{Retroviral misexpression}

RCAS-Noggin plasmid was the gift of Randy Johnson (M.D. Anderson Cancer Center, Houston, TX), and is described in Capdevila and Johnson (1998). Plasmid DNA was transfected into chicken embryonic fibroblasts, and virus was harvested, concentrated, and titered exactly as described (Morgan and Fekete 1996). Injections were performed at E3; concentrated viral supernatant was injected into a row of somites, between prospective forelimb and hindlimb, and embryos were reincubated until E8. For Alcian blue staining, embryos were beheaded and eviscerated in PBS, and transferred directly into staining solution $10.015 \%$ Alcian blue 8 GX in $20 \%$ acetic acid: $80 \%$ EtOH). After overnight staining, embryos were washed in 100\% EtOH, rehydrated down an EtOH: $\mathrm{H}_{2} \mathrm{O}$ series, and cleared briefly in $0.5 \% \mathrm{KOH}$ in $\mathrm{H}_{2} \mathrm{O}$. Once skeletal elements became visible (20-30 min), embryos were transferred to $1 \% \mathrm{KOH}$ in $20 \%$ glycerol in $\mathrm{H}_{2} \mathrm{O}$, until soft tissues were transparent (1-2 hr). Embryos were stored and photographed in $20 \%$ glycerol in $\mathrm{H}_{2} \mathrm{O}$.

\section{Acknowledgments}

We thank Haruhiko Koseki for the Pax1 probe; Ichiro Nishimura for the collagen IX cDNA; Tom Jessell for the BMP4 and BMP7 probes; Lee Niswander for the BMP-RIB probe; Randy Johnson for the RCAS-Noggin plasmid; Richard Harland for the
Noggin-expressing CHO cells; Genetics Institute for BMP proteins; Naomi Fukai for his in situ hybridization protocol; Bodo Christ and Lee Niswander for sharing unpublished information, Tom Schultheiss, Doug Spicer, Ram Reshef, and Miguel Maroto for encouragement and advice during the course of this work; and members of the Lassar laboratory for their comments on the manuscript. This work was supported by grants to A.B.L. from the National Science Foundation, the National Institutes of Health, and the Council for Tobacco Research. This work was done during the tenure of an established investigatorship from the American Heart Association to A.B.L. L.C.M. was supported by a predoctoral National Defense Science and Engineering Graduate fellowship from the Department of Defense.

The publication costs of this article were defrayed in part by payment of page charges. This article must therefore be hereby marked 'advertisement' in accordance with 18 USC section 1734 solely to indicate this fact.

\section{References}

Aoyama, H. and K. Asamoto. 1988. Determination of somite cells: Independence of cell differentiation and morphogenesis. Development 104: 15-28.

Avery, G., M. Chow, and H. Holtzer. 1956. An experimental analysis of the development of the spinal column. V. Reactivity of chick somites. J. Exp. Zool. 132: 409-425.

Borycki, A.-G., L. Mendham, and C.P. Emerson, Jr. 1998. Control of somite patterning by Sonic hedgehog and its downstream target genes. Development 125: 777-790.

Brand-Saberi, B., C. Ebensperger, J. Wilting, R. Balling, and B. Christ. 1993. The ventralizing effect of the notochord on somite differentiation in chick embryos. Anat. Embryol. 188: 239-245.

Brunet, L.J., J.A. McMahon, A.P. McMahon, and R.M. Harland. 1998. Noggin, cartilage morphogenesis and joint formation in the mammalian skeleton. Science 280: 1455-1457.

Buckland, R.A., J.M. Collinson, E. Graham, D.R. Davidson, and R.E. Hill. 1998. Antagonistic effects of FGF4 on BMP induction of apoptosis and chondrogenesis in the chick limb bud. Mech. Dev. 71: 143-150.

Buffinger, N. and F.E. Stockdale. 1994. Myogenic specification in somites: Induction by axial structures. Development 120: 1443-1452.

. 1995. Myogenic specification of somites is mediated by diffusible factors. Dev. Biol. 169: 96-108.

Capdevila, J. and R.L. Johnson. 1998. Endogenous and ectopic expression of noggin suggests a conserved mechanism for regulation of BMP function during limb and somite patterning. Dev. Biol. 197: 205-217.

Capdevila, J., C. Tabin, and R.L. Johnson. 1998. Control of dorsoventral somite patterning by Wnt-1 and $\beta$-catenin. Dev. Biol. 193: 182-194.

Chen, X., M.J. Rubock, and M. Whitman. 1996. A transcriptional partner for MAD proteins in TGF- $\beta$ signaling. Nature 383: 691-696.

Chevallier, A. 1975. Role du mésoderm somitique dans le développement de la cage thoracique de l'embryon d'oiseau. I. Origin du segment sternal et mécanismes de la différenciation des côtes. J. Embryol. Exp. Morphol. 33: 291-311.

1977. Origine des ceintures scapulaires et pelviennes chez l'embryon d'oiseau. J. Embryol. Exp. Morphol. 42: 275292.

Chiang, C., Y. Litingtung, E. Lee, K.E. Young, J.L. Corden, H. Westphal, and P.A. Beachy. 1996. Cyclopia and defective axial patterning in mice lacking Sonic hedgehog gene func- 
tion. Nature 383: 407-413.

Christ, B. and J. Wilting. 1992. From somites to vertebral column. Ann. Anat. 174: 23-32.

Christ, B., B. Brand-Saberi, M. Grim, and J. Wilting. 1992. Local signalling in dermomyotomal cell type specification. Anat. Embyrol. 186: 505-510.

Cossu, G., R. Kelly, S.D. Donna, E. Vivarelli, and M. Buckingham. 1995. Myoblast differentiation during mammalian somitogenesis is dependent upon a community effect. Proc. Nat1. Acad. Sci. 92: 2254-2258.

Deutsch, U., G.R. Dressler, and P. Gruss. 1988. Pax 1, a member of a paired box homologous murine gene family, is expressed in segmented structures during development. Cell 53: 617625.

Dietrich, S., F.R. Schubert, and P. Gruss. 1993. Altered Pax gene expression in murine notochord mutants: The notochord is required to initiate and maintain ventral identity in the somite. Mech. Dev. 44: 189-207.

Dietrich, S., F.R. Schubert, and A. Lumsden. 1997. Control of dorsoventral pattern in the chick paraxial mesoderm. Development 124: 3895-3908.

Dockter, J.L. and C.P. Ordahl. 1998. Determination of sclerotome to the cartilage fate. Development 125: 2113-2124.

Dosch, R., V. Gawantka, H. Delius, C. Blumenstock, and C. Niehrs. 1997. BMP4 acts as a morphogen in dorsoventral mesoderm patterning in Xenopus. Development 124: 2325 2334.

Duprez, D., E.J.d.H. Bell, M.K. Richardson, C.W. Archer, L. Wolpert, P.M. Brickell, and P.H. Francis-West. 1996. Overexpression of BMP-2 and BMP4 alters the size and shape of developing skeletal elements in the chick limb. Mech. Dev. 57: 145-157.

Ebensperger, C., J. Wilter, B. Brand-Saberi, Y. Mizutani, B. Christ, R. Balling, and H. Koseki. 1995. Pax-1, a regulator of sclerotome development is induced by notochord and floor plate signals in avian embryos. Anat. Embryol. 191: 297310.

Ellison, M.L., E.J. Ambrose, and G.C. Easty. 1969. Chondrogenesis in chick embryo somites in vitro. J. Embryol. Exp. Morph. 21: 331-340.

Ericson, J., S. Morton, A. Kawakami, H. Roelink, and T.M. Jessell. 1996. Two critical periods of Sonic hedgehog signaling required for the specification of motor neuron identity. Cell 87: 661-673.

Fan, C.-M. and M. Tessier-Lavigne. 1994. Patterning of mammalian somites by surface ectoderm and notochord: Evidence for sclerotome induction by a hedgehog homolog. Cell 79: 1175-1186.

Fan, C.-M., J.A. Porter, C. Chiang, D.T. Chang, P.A. Beachy, and M. Tessier-Lavigne. 1995. Long-range sclerotome induction by Sonic hedgehog: Direct role of the amino-terminal cleavage product and modulation by the cyclic AMP signaling pathway. Cell 81: 457-465.

Francis, P.H., M.K. Richardson, P.M. Brickell, and C. Tickle. 1994. Bone morphogenetic proteins and a signalling pathway that controls patterning in the developing chick limb. Development 120: 209-218.

Gamel, A.J., B. Brand-Saberi, and B. Christ. 1995. Halves of epithelial somites and segmental plate show distinct muscle differentiation behavior in vitro compared to entire somites and segmental plate. Dev. Biol. 172: 625-639.

Glaser, J.H. and H.E. Conrad. 1984. Properties of chick embryo chondrocytes grown in serum-free medium. J. Biol. Chem. 259: 6757-6765.

Goulding, M.D., A. Lumsden, and P. Gruss. 1993. Signals from the notochord and floor plate regulate the region-specific expression of two Pax genes in the developing spinal cord. Development 117: 1001-1016.

Grobstein, C. and H. Holtzer. 1955. In vitro studies of cartilage induction in mouse somite mesoderm. I. Exp. Zool. 128: 333-356.

Hall, B.K. 1977. Chondrogenesis of the somitic mesoderm. Springer-Verlag, Berlin, Germany.

Hamburger, V. and H.L. Hamilton. 1951. A series of normal stages in the development of the chick embryo. J. Morphol. 88: 49-92.

Harland, R.M. 1994. The transforming growth factor beta family and induction of the vertebrate mesoderm: Bone morphogenetic proteins are ventral inducers. Proc. Natl. Acad. Sci. 91: 10243-10246.

Hirsinger, E., D. Duprez, C. Jouve, P. Malapert, J. Cooke, and O. Pourquié. 1997. Noggin acts downstream of Wnt and Sonic Hedgehog to antagonize BMP4 in avian somite patterning. Development 124: 4605-4614.

Holtzer, H. and S.R. Detwiler. 1953. An experimental analysis of the development of the spinal column. III. Induction of skeletogenous cells. J. Exp. Zool. 123: 335-370.

Houston, B., B.H. Thorp, and D.W. Burt. 1994. Molecular cloning and expression of bone morphogenetic protein-7 in the chick epiphyseal growth plate. J. Mol. Endocrinol. 13: 289301.

Johnson, R.L., E. Laufer, R.D. Riddle, and C. Tabin. 1994. Ectopic expression of Sonic hedgehog alters dorsal-ventral patterning of somites. Cell 79: 1165-1173.

Kato, N. and H. Aoyama. 1998. Dermomyotomal origin of the ribs as revealed by extirpation and transplantation experiments in chick and quail embryos. Development 125: 34373443.

Kawakami, Y., T. Ishikawa, M. Shimabara, N. Tanda, M. Enomoto-Iwamoto, M. Iwamoto, T. Kuwana, A. Ueki, S. Noji, and T. Nohno. 1996. BMP signaling during bone pattern determination in the developing limb. Development 122: 3557-3566.

Kenny-Mobbs, T. and P. Thorogood. 1987. Autonomy of differentiation in avian branchial somites and the influence of adjacent tissues. Development 100: 449-462.

Kieny, M., A. Mauger, and P. Sengel. 1972. Early regionalization of the somitic mesoderm as studied by the development of the axial skeleton of the chick embryo. Dev. Biol. 28: 142161.

King, J.A., P.C. Marker, K.J. Seung, and D.M. Kingsley. 1994. BMP5 and the molecular, skeletal and soft-tissue alterations in short ear mice. Dev. Biol. 1994: 112-122.

Koseki, H., J. Wallin, J. Wilting, Y. Mizutani, A. Kispert, C. Ebensperger, B. Herrmann, B. Christ, and R. Balling. 1993. A role for Pax1 as a mediator of notochordal signals during the dorsoventral specification of vertebrae. Development 119: 649-660.

Kretzschmar, M. and J. Massagué. 1998. SMADs: Mediators and regulators of TGF- $\beta$ signaling. Curr. Opin. Genet. Dev. 8: 103-111.

Lamb, T.M., A.K. Knecht, W.C. Smith, S.E. Stachel, A.E. Economides, N. Stahl, G.D. Yancopolous, and R.M. Harland. 1993. Neural induction by the secreted polypeptide noggin. Science 262: 713-718.

Li, H., N.B. Schwartz, and B.M. Vertel. 1993. cDNA cloning of chick cartilage chondroitin sulfate (aggrecan) core protein and identification of a stop codon in the aggrecan gene associated with the chondrodystrophy, nanomelia. J. Biol. Chem. 268: 23504-23511.

Liem, K.F., Jr., G. Tremml, H. Roelink, and T.M. Jessell. 1995. Dorsal differentiation of neural plate cells induced by BMP. 
mediated signals from epidermal ectoderm. Cell 82: 969 979.

Liem, K. F., Jr., G. Tremml, and T.M. Jessell. 1997. A role for the roof plate and its resident TGF $\beta$-related proteins in neuronal patterning in the dorsal spinal cord. Cell 91: 127-138.

Lyons, K.M., B.L.M. Hogan, and E.J. Robertson. 1995. Colocalization of BMP-7 and BMP-2 RNAs suggests that these factors cooperatively mediate tissue interactions during murine development. Mech. Dev. 50: 71-83.

Macias, D., Y. Gañan, T.K. Sampath, M.E. Piedra, M.A. Ros, and J.M. Hurle. 1997. Role of BMP-2 and OP-1 (BMP-7) in programmed cell death and skeletogenesis during chick limb development. Development 124: 1109-1117.

Marigo, V., R.L. Johnson, A. Vortkamp, and C.J. Tabin. 1996. Sonic hedgehog differentially regulates expression of GLI and GLI3 during limb development. Dev. Biol. 180: 273-283.

Marcelle, C., M.R. Stark, and M. Bronner-Fraser. 1997. Coordinate action of BMPs, Wnts, Shh and Noggin mediate patterning of the dorsal somite. Development 124: 3955-3963.

Marti, E., D.A. Bumcrot, R. Takada, and A.P. McMahon. 1995. Requirement of $19 \mathrm{~K}$ form of Sonic hedgehog for induction of distinct ventral cell types in CNS explants. Nature 375: 322 325.

McMahon, J.A., S. Takada, L.B. Zimmerman, C.-M. Fan, R.M. Harland, and A.P. McMahon. 1998. Noggin-mediated antagonism of BMP signaling is required for growth and patterning of the neural tube and somite. Genes \& Dev. 12: $1438-1451$.

Monsoro-Burq, A.-H., M. Bontoux, M.-A. Teillet, and N. M. LeDouarin. 1994. Heterogeneity in the development of the vertebrae. Proc. Nat1. Acad. Sci. 91: 10435-10439.

Monsoro-Burq, A.-H., D. Duprez, Y. Watanabe, M. Bontoux, C. Vincent, P. Brickell, and N. LeDouarin. 1996. The role of bone morphogenetic proteins in vertebral development. $D e$ velopment 122: 3607-3616.

Morgan, B.A. and D.M. Fekete. 1996. Manipulating gene expression with replication-competent retroviruses. In Methods in avian embryology (ed. M. Bronner-Fraser), pp. 185-218. Academic Press, San Diego, CA.

Münsterberg, A.E., J. Kitajewski, D.A. Bumcrot, A.P. McMahon, and A.B. Lassar. 1995. Combinatorial signaling by Sonic hedgehog and Wnt family members induces myogenic bHLH gene expression in the somite. Genes \& Dev. 9: 2911-2922.

Ordahl, C.P. and N.L. Douarin. 1992. Two myogenic lineages within the developing somite. Development 114: 339-353.

Peters, H., U. Doll, and J. Niessing. 1995. Differential expression of the chicken Pax-1 and Pax-9 gene: In situ hybridization and immunohistochemical analysis. Dev. Dyn. 203: 116.

Pourquié, O., M. Coltey, M.-A. Teillet, C. Ordahl, and N.M. LeDouarin. 1993. Control of dorsoventral patterning of somitic derivatives by notochord and floor plate. Proc. Natl. Acad. Sci. 90: 5242-5246.

Pourquié, O., C.-M. Fan, M. Coltey, E. Hirsinger, Y. Watanabe, C. Bréant, P. Francis-West, P. Brickell, M. Tessier-Lavigne, and N.M.L. Douarin. 1996. Lateral and axial signals involved in avian somite patterning: A role for BMP4. Cell 84: 461471.

Re'em-Kalma, Y., T. Lamb, and D. Frank. 1995. Competition between noggin and bone morphogenetic protein 4 activities may regulate dorsalization during Xenopus development. Proc. Natl. Acad. Sci. 92: 12141-12145.

Reshef, R., M. Maroto, and A.B. Lassar. 1998. Regulation of dorsal somitic cell fates: BMPs and Noggin control the timing and pattern of myogenic regulator expression. Genes \& Dev. 12: 290-303.
Roark, E.F. and K. Greer. 1994. Transforming growth factor- $\beta$ and bone morphogenetic protein-2 act by distinct mechanisms to promote chick limb cartilage differentiation in vitro. Dev. Dyn. 200: 103-116.

Rong, P.M., M.A. Teillet, C. Ziller, and N.M.L. Douarin. 1992. The neural tube/floor plate/notochord complex is necessary for vertebral but not limb and body wall striated muscle differentiation. Development 115: 657-672.

Sanders, E.J. 1997. Cell death in the avian sclerotome. Dev. Biol. 192: $551-563$.

Schmidt, J.E., A. Suzuki, N. Ueno, and D. Kimelman. 1995. Localized BMP4 mediates dorsal/ventral patterning in early Xenopus embryos. Dev. Biol. 169: 37-50.

Spence, M.S., J. Yip, and C.A. Erickson. 1996. The dorsal neural tube organizes the dermamyotome and induces axial myocytes in the avian embryo. Development 122: 231-241.

Stern, H.M. and S.D. Hauschka. 1995. Neural tube and notochord promote in vitro myogenesis in single somite explants. Dev. Biol. 167: 87-103.

Stern, H.M., A.M.C. Brown, and S.D. Hauschka. 1995. Myogenesis in paraxial mesoderm: Preferential induction by dorsal neural tube and by cells expressing Wnt-1. Development 121: 3675-3686.

Swiderski, R.E. and M. Solursh. 1992. Localization of type II collagen, long form $\alpha 1$ (IX) collagen, and short form $\alpha 1$ (IX) collagen transcripts in the developing chick notochord and axial skeleton. Dev. Dyn. 194: 118-127.

Teillet, M.-A., Y. Watanabe, P. Jeffs, D. Duprez, F. Lapointe, and N.M.L. Douarin. 1998. Sonic hedgehog is required for survival of both myogenic and chondrogenic somitic lineages. Development 125: 2019-2030.

Tonegawa, A., N. Funayama, N. Ueno, and Y. Takahashi. 1997. Mesodermal subdivion along the mediolateral axis in chicken controlled by different concentrations of BMP4. Development 124: 1975-1984.

Vasios, G., I. Nishimura, H. Konomi, M.v.d. Rest, Y. Ninomiya, and B.R. Olsen. 1988. Cartilage type IX collagen-proteoglycan contains a large amino-terminal globular domain encoded by multiple exons. J. Biol. Chem. 263: 2324-2329.

Vivarelli, E. and G. Cossu. 1986. Neural control of early myogenic differentiation in cultures of mouse somites. Dev. Biol. 117: 319-325.

Watterson, R.L., I. Fowler, and B.J. Fowler. 1954. The role of the neural tube and notochord in development of the axial skeleton of the chick. Am. J. Anat. 95: 337-399.

Williams, B.A. and C.P. Ordahl. 1997. Emergence of determined myotome precursor cells in the somite. Development 124: 4983-4997.

Zimmerman, L.B., J.D. Jesus-Escobar, and R.M. Harland. 1996. The Spemann organizer signal noggin binds and inactivates bone morphogenetic protein-4. Cell 86: 599-606.

Zou, H., R. Wieser, J. Massagué, and L. Niswander. 1997. Distinct roles of type I bone morphogenetic protein receptors in the formation and differentiation of cartilage. Genes \& Dev. 11: 2191-2203. 


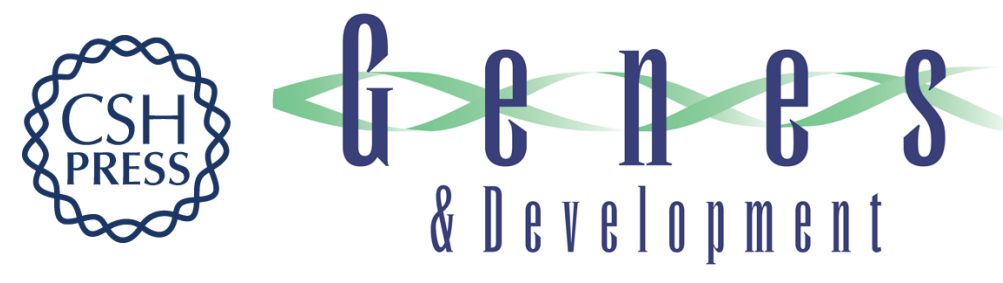

\section{Sonic hedgehog promotes somitic chondrogenesis by altering the cellular response to BMP signaling}

L. Charles Murtaugh, Jay H. Chyung and Andrew B. Lassar

Genes Dev. 1999, 13:

References This article cites 79 articles, 38 of which can be accessed free at:

http://genesdev.cshlp.org/content/13/2/225.full.html\#ref-list-1

License

Email Alerting

Receive free email alerts when new articles cite this article - sign up in the box at the top

Service right corner of the article or click here.

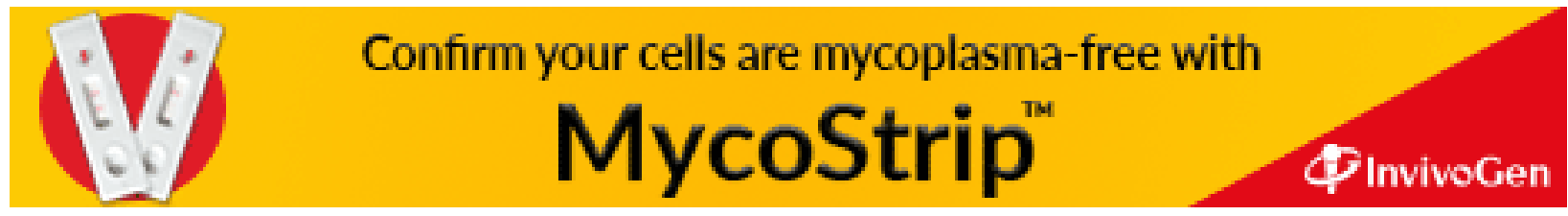

